\title{
Hydropower Policy and Site-Level Contestation under the Political Transition: Challenges for Ending the Power Cut in Nepal
}

Hari Dhungana $^{1 *}$ and Gyanu Maskey ${ }^{1}$

${ }^{1}$ Southasia Institute of Advanced Studies (SIAS), Minbhawan, Kathmandu.

${ }^{*}$ Corresponding author: h.dhungana@gmail.com

\section{Abstract}

The growing optimism for hydropower development in Nepal over the past few years faces significant bottlenecks amid the country's political transition. The government's policies to attract more and more investment in new hydropower projects face the challenge of retaining investors and bringing projects to success, as considerable confusion and uncertainty exist around environmental and social-political demands on the projects. Ongoing political transition retains and harbours greater grey area for local and indigenous rights, labor issues, grievance handling, site-level decision-making, and responding to the widespread resort to obstructionism, blockages, and strikes. This paper draws on the evidence and insights from the case study of hydropower project in Western Nepal and a series of meetings in Kathmandu with water sector stakeholders to identify key challenges for the development and implementation of hydropower projects in terms of physical and social impacts. To achieve policy goals on hydropower development, it is essential to have policy-legal clarity on the above issues in a manner that is understood and legitimated by local stakeholders, and internalized into decision-system at the local level. These conditions will be rendered feasible only with the end of ongoing political transition in favour of a stable, transparent and democratic polity in the country.

Keywords: Hydropower development, social and environmental safeguards, international norm.

\section{Introduction}

Hydropower is often viewed in Nepal as an opportunity for lifting the country's population out of poverty, an essential component of infrastructure for industries and an epitome of development. Over the past few years, a feeling of optimism for hydropower development has been growing in Nepal. It is expected to end the power cuts going on for over a decade. The government and the private sectors are actively pursuing new hydropower projects in different parts of the country. The annual peak power demand is soaring at the rate of $7.56 \%$ (compared to the preceding 2013-14 fiscal year's figure of $1201 \mathrm{MW}$ ). The annual peak power demand of the Integrated Nepal Power System (INPS) in fiscal year 2014/15 was 1,291.80 MW, with $585 \mathrm{MW}$ load shedding. Out of the power actually supplied, 357.68 MW was contributed by NEA hydro, 124.771 MW by IPP hydro and the rest 224.41 MW was imported from India (NEA, 2015). Till September 2014, the government provided license to 92 new hydropower projects with combined capacity for 2,400 MW (DOED, 2014). Most of the power plants are run-ofriver type with energy available in excess of the in-country demand during monsoon and deficit during dry season.

At the same time, hydropower development is facing significant bottlenecks amid the country's political transition. Technical problems are always put at the forefront, but our concern is with politics. How 
politicians deal with technical problems is really significant. Political instability, lack of good governance and law and order issues are important factors hindering progress and economic growth (Aisen and Veiga, 2013). Ongoing political transition retains and harbours greater grey area for local and indigenous rights, labor issues, grievance handling, site-level decision-making and responding to the widespread resort to 'contentious politics' techniques, such as obstructionism, blockages and strikes. The vacuum of elected local leadership and an absence of effective political dissent provide a fertile ground for misrepresenting local interests and siphoning public and project resources along local powerful interests. Thus irrespective of policy and statutory provisions on environment and social aspects, local patronage politics is likely to intermesh with the model of justice developed in Nepal's policy on hydropower development.

This paper draws on the evidence and insights from the authors' case study of a hydropower project in Western Nepal (Upper Marshyangdi-A Hydropower Project in Bhulbhule, Lamjung) and a series of meetings in Kathmandu with water sector stakeholders. We explore the bottlenecks in hydropower development in Nepal amid the country's political transition. This includes the uncertainty existing around environmental and socialpolitical demands on the projects, local and indigenous rights, labor issues, grievance handling, site-level decision-making and responding to the widespread resort to 'contentious politics techniques, such as obstructionism, blockages and strikes.
We emphasize that power developers more recently face a series of demands on social and environmental safeguards and are increasingly required to negotiate and settle project development complications to a variety of local actors, beyond the state authorities that were supposed to have a sole decision power. In particular, the project developers have to engage and comply with international norms around dam and development, national laws and procedures, and a wide variety of local claims and contestations around environmental and social issues. Project developers face the challenges of reconciling these demands in an open and transparent way and presently lack effective institutional mechanisms for brokering the difference. We argue that there is a need for establishing coherence of social and environmental safeguards and standards and their more effective implementation.

In this paper, we aim to articulate ways forward for more successful implementation of hydropower policies, for which we explore the opportunities and bottlenecks in hydropower development in Nepal during the protracted political transition of the recent past. In particular, the research explores the hydropower policy provisions attracting investments in hydropower development in Nepal; policy provisions addressing the local peoples' benefits and the challenges in hydropower projects in relation to the environmental and social-political demands.

\section{Materials and methods}

The paper is based on literature review of the hydropower policies and the relevant studies. A case-study was conducted in the Upper Marsyangdi-A Hydropower Project 
in Bhulbhule, Lamjung. A basic household livelihood survey ${ }^{1}$ was conducted in the six village hamlets immediately surrounding the project site: Tanglinchok, Taranche and Nyadi Bazaar located in Ward 5 of the VDC, Nandeshwora-Jyamire (Ward 4), Bhulbhule Bazaar (Ward 3) and Kuwapani/ Kuleshwor (Ward 2). These villages have a total of 176 households. For this we conducted household questionnaire survey, through stratified sampling (with ethnicity/caste and wealth ranking) with respondents from a total of 37 households. Semi-structured interviews, stakeholder consultation, focused group discussions and observation were done in the casestudy site.

\section{Hydroelectricity in Nepal}

Nepal possesses a network of over 6000 rivers - big and small - that flow southwards to the flatland Terai and ultimately drain into the Ganges in India. For over five decades, it has been popularized that these rivers have the potential of generating $83000 \mathrm{MW}$ of hydroelectricity (Dixit and Gyawali, 2010), and estimates suggest that Nepal's technoeconomically viable capacity is $43,000 \mathrm{MW}$ (WECS, 2010). But while Nepal passes through a hundred years of hydroelectricity generation, which started in 1911 for lighting the palaces in Kathmandu, $40 \%$ of the country's population still does not have access to electricity.

Owing to the annual peak power demand of the Integrated Nepal Power System (INPS) of 1,291.80 MW (Fiscal year 2014-15), only $706.861 \mathrm{MW}$ is supplied (357.68 MW by NEA hydro, 124.771 MW by IPP hydro and 224.41 MW from India), resulting in 285 MW load shedding. Even those who have access have been experiencing power cuts that go beyond 84 hours a week for the past several years. Indeed, having confronted daily power outages (called "load shedding"), the government of Nepal declared a state of energy emergency on 23rd March 2011 (TAF and NITI, 2012). This acute shortage of electricity in the backdrop of a high potential for generation and a relative peace after the end of Maoist insurgency (1996-2006) have ushered in a newfound enthusiasm for domestic and international actors in investing in the hydropower sector. Accordingly, as revealed by the Department of Electricity Development (DOED) data, the government has provided license to 92 new hydropower projects with combined capacity for $2400 \mathrm{MW}$ (DOED, 2014). But as these projects start construction, many of them are likely to face issues that have been debated at least from early 1990s, around the environmental and social concerns surrounding hydropower development.

\section{Political transition and hydropower policy provisions attracting investments}

The 'political transition' in Nepal, characterized by absence of effective political dissent, provides a fertile ground for misrepresenting local interests and siphoning public and project resources along local powerful interests. Thus irrespective of policy and statutory provisions on environment and social aspects, local patronage politics is likely to intermesh with the model of justice 
developed in Nepal's policy on hydropower development. Despite the national process of democratization, local politics in rural Nepal remains often dominated by 'distributional coalitions': local powerbrokers team up to control the local population's access to services provided by District and Village Development Committees (Pfaff-Czarnecka, 2008). The powerbrokers typically include government bureaucrats, politicians, businessmen and important school teachers (Hachhethu, 2008; Sharrock, 2013).

The government policies have tried to attract more and more investment in new hydropower projects. However, these face the challenge of retaining investors and bringing projects to success, as considerable confusion and uncertainty exist around environmental and socialpolitical demands on the projects. Some of the hydropower policies that attract investment on hydropower development are discussed below:

The governments in post-1990 period faced greater demand for domestic production and for capturing opportunities for investment and job creation and also for strengthening political clout by showcasing hydropower as a development. By the time new government came after the political change in 1990, Nepal had a total installed capacity of 278 MW (with 233 MW of Hydropower and $45 \mathrm{MW}$ of diesel power) and it was projected that Nepal urgently needed an additional capacity of $300 \mathrm{MW}$ to $400 \mathrm{MW}$. There was also a problem that many remote areas of the country were not connected to the national grid operated by Nepal Electricity authority.
Thus governments in post-1990 period were intent on securing investment and supplying electricity to new areas.

As the new government came in 1991 with the parliamentary election, it embarked resolutely on the policies of open market and liberalization. The government made swift steps for expediting liberalization, market reforms and encouragement of the private sector. This approach came through the eight five-year plan (1992-1997) and Hydropower Development Policy of 1992. While earlier, Nepal Electricity Authority (NEA) - which is a government-owned forprofit entity - had a monopoly over power generation, transmission and distribution, the post-1990 policies pursued to break the monopoly and invite domestic and foreign investors. The Hydropower Policy of 1992 and subsequent Water Resources Act (1992) outlined the policy and procedures for generating, distributing and exporting hydroelectricity by the domestic private sector, foreign investors, community producers as well as the NEA. These policies paved way for introduction of the 'build, own, operate and transfer' (BOOT) model of hydropower project development. The main intent was to facilitate private sector investment and clarify procedures for the same (Adhikari, 2006). It did so by setting provisions on licensing, power purchase agreement, tariff fixation, acquisition of land and environmental conservation.

After the entry of Maoists into 'mainstream' and the election of constituent assembly I in particular, successive governments have made announcements for electricity generation by setting ambitious targets. The Maoist-led government which came 
after 2008 announced the generation of $10,000 \mathrm{MW}$ of electricity in ten years (by 2020), while the next government led by Communist Party of Nepal (Unified Marxist-Leninist) doubled that target to 25,000 MW to be achieved in the next twenty years. Some of the policies that attract investment in hydropower are explained below:

\section{Acquisition of land}

The 1992 hydropower development policy (HDP, 1992) envisioned that the government would acquire land upon request of hydropower and the government would use Land Acquisition Act of 1977 for the same. With it, the government mobilizes its principle of imminent domain to assert state authority in claiming private property. However, the hydropower development 2001 policy (HDP, 2001) encourages the private sector to acquire the land and houses in the areas for the generation, transmission and distribution of hydropower, while promising support required to acquire land.

Further, the 2009 Plan highlights the need for simplifying the process of land acquisition. It also mentions that the "rate of compensation for acquired land should not at all circumstances be less than the average of prevailing price." It also suggests that there will be provisions to enable the previous landowners of such acquired land to invest up to $50 \%$ of the compensation amount as equity on the project (MOE, 2009, section 6).

\section{Demands of Locals}

The report of the Twenty-Year Hydropower Development Plan Formulation Task Force (MOE, 2010) projects local people as a problem. It identifies that the project implementation faces the problem as local people put forward unfair demands and cause disruption in the construction work and thus the government should mobilize local social institutions and political party cadres in sensitizing local people and to have regular dialogues between the project and local representatives about what demands the project can meet and what not (MOE, 2010, p.25).

\section{EIA}

The government brought out a 38-point Electricity Crisis Resolution Action Plan in 2009. It provides several concessions around investment, but also provides waiver of the provision conducting Environmental Impact Assessment (EIA) for power projects. Such a power project will be required to do Initial Environmental Examination (IEE) only.

\section{Resettlement and Rehabilitation}

The Hydropower policy (HDP) 2001 states that the investors shall be provided with assistance in regard to resettlement and rehabilitation by the government but that the former will have to bear the resources required.

\section{Policy provisions addressing the local people's benefits}

\section{Royalty distribution}

The hydropower policies and legislation relate to provisions on royalty, its distribution between central government 
and local government and the benefits entitled to local people. In the Hydropower Development Policy of 1992 and Electricity Act 1992, the provision is made for hydropower developers to pay royalty to central government, while subsequent local governance legislation and hydropower policy of 2001 also provided for sharing royalty between central government and local governments. With introduction of Local Self Governance Act 1999 and Regulations 2000, the central government is required to provide $50 \%$ of electricity revenue to the respective district where power house is located $(12 \%)$ and the development region (38\%).

The ten-year plan also recommends that the project should provide an amount equivalent to one percent of total project cost to the local government in the project area (MOE, 2009, section 8). Local Self Governance legislation provisioned to redistribute hydropower royalty to communities in the vicinity of projects. The Hydropower Policy 2001 suggested a provision to return $10 \%$ of the royalty from a hydropower project to the district where it is located. In 2004, the second amendment of the Self-Governance regulations increased the district's share of the royalty to $12 \%$. In response, the new Electricity Ordinance (2007) made provision to share electricity royalties from a hydro-project between the concerned DDCs $-12 \%$ which is then redistributed to VDCs adjoining the project (Mathema et al., 2013).

\section{Use of local labor and skills}

In regard to local people, the hydropower policy of 1992 mentions that projects should be operated in a way that the local people are also directly benefited from such projects. It also encourages the use of local labor and skills, and for foreign investors to transfer technology to Nepalese citizens. These provisions of the policy however do not find a concrete expression in the Electricty Act of 1992. The hydropower policy of 2001 also mentions similar points about benefit to local people, but it reaffirms the provisions of local governance legislation to share revenue with local governments.

\section{Water Rights}

The 1992 policy is silent on water rights of local people, whereas the 2001 policy indicates that legal provisions will be made to prevent adverse effects on the availability of water.

\section{Compensation for harms}

There are no clear provisions in regard to multiple harms that the local people would suffer from project development, and on the ways such harms could be redressed. The implicit assumptions seem to be that the EIAs identify the potential harms and those recommendations offered to mitigate or compensate them.

\section{Resettlement and Rehabilitation}

Unlike the 1992 policy, which is silent on the resettlement of project affected people, the 2001 Hydropower policy encourages the development of large storage and multipurpose projects. It mentions that the project has to rehabilitate and resettle the families to be displaced while generating, transmitting and distributing electricity in accordance with the standards set by the Government of Nepal. The standards, however, have not been developed, and in 
the consultation on dam and development in early 2000s, Nepal government and hydrocracy rejected the Dam and Development report, but upon more considered reviews they got convinced that many provisions were already internalized into existing policy regime and are convinced of the need to engage with Dam and development report (Dixit and Gyawali, 2010). The ten-year plan indicates the need for developing a National Resettlement policy for the cases when people will be displaced and need rehabilitation in the course of the development of hydropower projects.

\section{Consultation and Consent of Indigenous} and Local Communities for Project Development

The hydropower policies - both of 1992 and 2001- and legislations are silent on the idea of consultation and consent on local and indigenous people. There is, however, provision in Environment Impact Assessmentaboutlocal consultation, butthat is primarily for identifying environmental impacts, and such consultation falls short of political space for the participation of local and indigenous people, at least in the way the demands for Free, Prior and Informed Consent (FPIC) is made from indigenous groups.

The ten-year plan also mentions the rights of local people. It envisages that arrangements to be made in projects under domestic or foreign investment for providing "the ordinary people, laborers, and local bodies (i.e., local governments)" such investment instruments as convertible debentures, preferential shares, labor bonds and power bonds according to their respective capacity. It also recommends providing suitable training to local human resource.

The Twenty-Year Plan further identifies as an issue the maximum benefits that local people are entitled to, in the "context that concerns being raised about local people's rights around hydropower projects (MOE, 2010, p.57).

\section{Environmental Protection, Its Norming into EIA and Implementation}

There was no clear environmental law during the formulation of 1992 electricity act and the hydropower development policy. Both these policy and legislation mentioned that the hydropower projects have minimum adverse impact on the environment. However, after the introduction of Environmental Protection Act (1996) and Regulations (1997), environmental standards were enforced in a wide variety of projects. The regulations categorized projects that required environmental impact assessment (which are generally likely to have greater impacts) and initial environmental examination (IEE) for smaller projects.

2001 Hydropower Policy was more categorical on environmental conservation. For instance, it specifies the minimum of river flow that should remain as the natural flow - not diverted to hydropower tunnel(whichever is greater amongst the amount specified in the EIA or $10 \%$ of river flow). It also foresees the displacement and rehabilitation of people caused by hydroprojects. 
The ten-year plan makes specific provisions on environmental impact assessment. It suggests that arrangements will be made to simplify EIA and its approval, and to specify approval timeline. The twenty-year plan (MOE, 2010, p.56) recommends that the hydropower development should also go forward in national parks and other protected areas, should that be feasible as seen from EIA, but that would need loosening restrictions in the relevant protected area laws.

The Environmental Protection Act 1996 and Regulations $^{2} 1997$ require the mandatory application of Environmental Impact Assessment (EIA) for projects above $5 \mathrm{MW}$ and Initial Environmental Examination (IEE) for projects between 1 and $5 \mathrm{MW}$. These provisions are made to ensure the mitigation of any negative environmental and social impacts of the project. However, developers have been complaining about the bureaucratic problems created by this provision.

\section{Case study site}

The study was carried out in Upper Marsyangdi-A Hydropower Project. Its construction started in 2012 in Bhulbhule Village Development Committee (VDC) of Lamjung district in Western Nepal. It is a run-off river hydroelectric project and its construction site is located on the left bank of Marsyangdi River. The project received the hydropower generation license from the Department of Electricity Development in April 2012 for a period of 35 years (to expire in April 2047) and has an installation

${ }^{2}$ According the Regulations, projects with generation capacity of more than $5 M W$ require EIA. capacity for the generation of $50 \mathrm{MW}$ of electricity (DOED, 2014). This project is a joint venture operated by Sino Hydro Sagarmatha Power Company Ltd, with a license as a 'build, own, operate, and transfer' (BOOT) model, with an estimated cost of NPR 10 billion. This is the first Chinese investment in hydro project in Nepal. The project has signed a power purchase agreement with the Nepal Electricity Authority for 6.95 cents per unit $(\mathrm{KWh})$ and is scheduled to start production by October 2016 .

\section{Site level challenges for managing hydro-electric projects}

\section{Fulfillment of Social and Local/ Indigenous Demands and Concerns}

The hydropower developers and investors have to getalong the challenges in addressing the local people's demands that are raised time and again, and followed by number of strikes, blockages and obstructions. The case of Upper Marsyangdi-A Hydropower Project also presents some instances of local demands and how these led to obstructionism, blockages and strikes. Although the villagers acknowledged the benefits due to the construction of the hydropower project, they demanded the company to undertake remedial actions against avoidable losses, pay compensation for unavoidable losses and provide further benefits to the local population. This included several demands on increasing the wages of the laborer, addressing the impact due to blasting, adopting Free Prior and Informed Consent for which the local and indigenous people halted the projects several times. The attention was even sought by the case of a girl's death in Chare khola of adjacent Khudi VDC in 
which the locals obscured the project work and demanded for the bridge construction and compensation to the affected family. The indigenous and local people have the concern that consultation FPIC (Free, Prior and Informed Consent) is to be done prior to any project. Nepal Federation of Indigenous Nationalities (NEFIN) has been advocating the right of the indigenous nationalities and also led the labours strike in February 2014 raising the issue of FPIC (Free-prior-Informed-Consent).

Despite people's getting employment opportunities due to the project, some were suspicious if the company had done enough to generate local jobs. Although the company was required by Nepali regulations and the EIA to give preference to local workers, many villagers were convinced that the company hired more workers from other areas than it had to. They did not believe the company's justification that they had to turn to external labor because local workers did not possess the required skills. They noted that in some cases the company employed external workers where villagers actually had the required skills, and that the company had not provided the training courses set out in the EIA and budgeted in the construction project.

\section{Addressing Compensation and Harms}

There are no clear provisions in regard to multiple harms that the local people would suffer from project development, and on the ways such harms could be redressed. The implicit assumptions seem to be that the EIAs identify the potential harms and those recommendations offered to mitigate or compensate them. Villagers were concerned with the dust generated by the company vehicles that would cause damages to their health and resented its effects on shops, houses and agricultural fields along the road. Although the company sent their trucks to sprinkle water as per the people's request, in few instances, when the company drivers did not follow their requests, villagers simply blocked off the road for a few hours until the company sent the next water truck.

The assertion of claims and payment of compensation for the cracks developed by the explosions set off by the company was never a clear and straight forward process, neither in the case of cracks nor for the four households which had to leave their houses for the heaviest construction period -- the one household that had to relocate permanently, or the one whose agricultural land the company occupied for three years. Company officials complained in unison that 'people are never satisfied' and 'demands are always exaggerated' although they considered the compensation amounts 'very good'. 'Yet, the company had to give in to villagers' demands at least in parts because 'the company has its own time pressure to finish in three years'. They had to negotiate with villagers since they could not simply meet villagers' demands. Villagers, in turn, did not tire stressing and inflating the costs and losses imposed by the construction on them.

\section{Grievance Handling}

Site-level challenges are also seen prevalent in dealing with grievance handling. The difficulty also lies in brokering and negotiation between the project and the local people. Public Concern Committees (PCC) formed to mediate between people and project to express people's concerns to the project and project's problems 
back to the people and facilitate smooth operation of the project, is accused of not fully acknowledging the local indigenous rights and not in favor of the local people as plunged with own vested interestsintermeshed with local patron politics. Many complained that the Committee hired local workers through their personal and party networks, and that they often preferred hiring workers from other areas since they could charge them a commission. A woman captured this by using the concept of afno manche commonly used in Nepal to refer to favoritism in the allocation of jobs, contracts, and other benefits. However, the PCC members find it challenging to satisfy both parties. People also informed that, in addition to favoring their own people, the PCC members are likely to take some commission for the employment.

That is to say, the preferential hiring of local labor also reinforces a form of patronclient relationship - on the basis of family relationships and party affiliations. The provision of job is also allegedly associated with commission/rent-seeking, at least in some instances. The local people complain about the representation of the PCC, and that the PCC takes side of the project and represent the project rather than addressing the local people's concerns.

\section{Conclusion}

Policies since 1990 in Nepal have encouraged the investment in hydropower project from the private section, by clarifying the processes of licensing, environmental impact assessment, land acquisition and compensation, project security arrangements, concession around investment and others. The policies and laws have also provisioned for the rights and entitlements of local populations, including 'local people' and indigenous groups, benefit sharing, use of local labors, compensation for harms, rehabilitation and resettlement, environmental norming and others.

Besides the policies provisions and arrangements, the challenges lie at the site level project implementation in response to the increasing local and social demands. The issue brought up by the Upper Marshyandi a hydropower construction is an example that would soon arise in other construction sites of Nepal. There is a need for establishing coherence of social and environmental safeguards and standards and their more effective implementation. The intermediaries also form a part of patronage politics - across party organizations, ethnic/caste, traditional dominance in local spaces and the activist spaces also tend to be captured by the 'intermediaries' - that vacillate between their private interests and the community interests as they negotiate with the project.

The development of the hydropower project in the long run is beneficial. Hence, cooperation among the local people and the intermediaries would help in smooth completion of the work and the village development. Hence, negotiations are necessary; people should have the just demands and the project authorities also should make sure that the environment and the social harmony is maintained. There seems to be a good opportunity for the project to set an example for the lessons to be learnt by the upcoming projects. The future of hydropower development in Nepal is promising provided that the issues are wisely handled. 


\section{Acknowledgement}

The authors would like to acknowledge the generous support of UK Economic and Social Research Council and Department for International Development as funder of the project "Rethinking Environment and Development in the Era of Global

\section{References}

Adhikari, D. 2006. Hydropower Development in Nepal, Economic Review, 18: 70-94.

Aisen, A. and Veiga, F.J. 2013. How Does Political Instability Affect Economic Growth? European Journal of Political Economy, 29:151-167.

Dixit, A. and Gyawali, D. 2010. Nepal's Constructive Dialogue on Dam and Development. Water Alternatives, 3(2): 106-123.

DOED. 2014. List of Issued Generation Licenses. Available on Department of Electricity Development (DOED), Ministry of Energy, Water Resource and Irrigation. http://www.doed.gov.np/construction license for generation.php; assessed on 14th June 2014.

Hachhethu, K. 2008. Local Democracy and Political Parties in Peal: A Case Study of Dhanusha District. In: D. N. Gellner and K. Hachhethu (Eds.). Local Democracy in South Asia: Microprocesses of Democratization in Nepal and its Neighbours. New Delhi: SAGE, 45-70.

HDP. 1992. Hydro-power Development Policy (HDP). Department of Electricity Development, Ministry of Energy. website: http:// www.doed.gov.np/policy.php

HDP. 2001. Hydropower Development Policy (HDP). Department of Electricity Development, Ministry of Energy. website: http:// www.doed.gov.np/policy.php

Mathema, A.B., Guragain, S., Sherpa, N.C. and Adhikari, B.B. 2013. Can Hydropower Drive Green Economy for Nepal: a review. Journal of Environmental Protection, 4(7): 732-740.
Norms (REDEGN)". The research was conducted during 2013-2015. We thank the representatives from Public Concern Committee, Environment Management Unit, Public Relation Officer, NEFIN and the local people for their support and coordination in the study.

MOE, 2009. Report of the Ten-Year Hydroelectricity Development Plan Formulation Task Force, Kathmandu, Nepal/ Ministry of Energy (MOE). website http://www. moen.gov.np/

MOE, 2010. Report of the Twenty-Year Hydroelectricity Development Plan Formulation Task Force, Kathmandu, Nepal/ Ministry of Energy (MOE). website http://www.moen.gov.np/

NEA, 2015. Annual Report. Nepal Electricity Authority (NEA). Available at: www. nea.org.np.

Pfaff-Czarnecka, J. 2008. Distributional Coalitions in Nepal: An Essay on Democratization, Capture, and (Lack of) Confidence. In: D.N. Gellner and K. Hachhethu (Eds). Local Democracy in South Asia: Microprocesses of Democratization in Nepal and its Neighbours. New Delhi: SAGE, 71-104.

Sharrock, J. 2013. Stability in Transition: Development Perspectives and Local Politics in Nepal. European Bulletin of Himalayan Research, 42: 9-38.

TAF. and NITI. 2012. A Political Economy Analysis of Electricity Tarrif Restructuring in Nepal. The Asia Foundation (TAF) and NITIFoundation. Kathmandu, Nepal.

WECS, 2010. Energy Sector Synopsis Report 2010. Water and Energy Commission Secretariat (WECS), Kathmandu, Nepal. 